\title{
Political and Socio-Economic Obstacles to Implementation the Convention on Rights of Child in Central African Republic
}

\author{
First Moga-Kpely Aurelie-Clemence ${ }^{1}$, Second Yang Zewei ${ }^{2}$ \\ ${ }^{\prime}$ (School of Law, Wuhan University, People's Republic of China) \\ 2 (School of Law, Wuhan University, People's Republic of China)
}

\begin{abstract}
Central African Republic, which ratified International convention on the rights of the child in July 1990, was committed to respect and protect the rights of children CAR. However, despite its promise, the country faces significant challenges: political, economic and socio-cultural obstacles that still limit the full enjoyment of the rights of children. Our research aims at drawing attentions on the need to promote child's rights in all the country as the key to prevent violation. Consequently the study gives suggestions to those dealing with child labor, to institutions of justice for child, and then emphasizes the need to sensitize populations on the importance of protecting and defending children's rights.
\end{abstract}

Keywords: Culture, Human Rights, International Law, Protection of the child

\section{INTRODUCTION}

United Nations Millennium Goals launched in 2000 to promote a better world has profoundly reoriented States' policies. The declaration enunciating those objectives mainstreams the importance of children in assigning public as well as private decision makers the obligation to provide the child with means to peacefully carry out his/her abilities in his/her growth and development process. The United Nations Convention on the Rights of the Child in 1989, that took into account the Geneva Convention of 1924 and the Declaration of 1959 , emphasized the special nature of child protection. By this act, the international organization expressed the need to strongly promote the welfare and personal benefits of the child. In doing so, it obliges legislatures to comply as much as possible laws in adoption and modification process with children's interests. Therefore Conventions on the Rights of the Child bind signatory states as any other international law [1]. This requirement points out the issue of possible changes in some provisions of domestic laws in the aim of giving effect to treaty's obligations. A second principle [2] poses the problem of structures, administrative or judicial, and resources, human as well as material, to effectively guarantee to children the enjoyment of rights resulting from international obligations. Unfortunately, the rights of the child are not fully implemented in many countries including the Central African Republic. This study aims to investigate political, economic and social causes of the situation so as to propose sustainable solutions.

\section{Political Obstacles}

Central African Republic is as a vast territory where social crises are recurrent [3]. In recent years, the country has fallen into a vicious cycle of internal conflicts between the central government and rebel groups. This situation of permanent rebellion had terrible affected the economic and socio-cultural development, making the country one of the world poorest according to the Human Development Index. Therefore, children's welfare issue is relegated to the second rank in national programs of the successive governments. This situation is even more worrying as the country is bound by several international conventions including the Convention on the Rights of the Child. The application of international standards obeys specific internal procedures of the state ratification, publication, incorporation. However, it remains subjected to the political context of the country and its economic and social development.

\subsection{Political Instability in Central African Republic - CAR}

CAR has been facing politico-military crises for more than 20 years. Since 2005, governmental forces are opposed to armed groups and populations are main victims of the extreme violence resulting from fights. Particularly in 2008, a peace agreement was signed and amnesty law adopted to cease fire in all the country. Unfortunately, the north side always remained on hot coals. Let remind that the former president François Bozizé took over the power after a putsch in 2003. Height years later, he organized presidential elections that he won in January 2011. But his popularity and legitimacy was continuously disputed by populations in the country. As a consequence, a coalition of protesting groups know as "SELEKA" was formed and started a new military crisis that led to the reversal of presidential power in the country on the 24 January 2013. 


\subsection{Phenomenon of Child Soldiers}

An increasing number of children are recruited by both rebels and pro-governmental militias in Central African Republic. According to UNICEF, about 2,500 children, girls and boys, were already found in armed and vigilante groups in the country before the conflict's bursting in December [4]. Since then, this practice, which is a serious violation of the rights of the child, has grown and the international organization is actually unable to give a precise count. Young people, especially those who are separated from their families, are forced to fight and to carry heavy loads, at risk of being sexually abused. Seleka rebellion triggered hostilities in December 10, 2012. Until the coup of 24 March 2013, all the 16 prefectures of the Central African Republic were affected by massive and repeated violations of human rights including children's rights. Even the capital city Bangui is confronted with the problem.

\section{ECONOMIC AND SOCIAL OBSTACLES}

\subsection{Poverty Issue}

Poverty is not a recent phenomenon. It affects millions of people as well in industrialized as in developing countries. In Sub-Saharan countries in Africa in general and particularly in CAR, its progression is alarming. Social indicators place the CAR among the poorest countries of the world [5]. Moreover, most recent data coming from investigations in households indicate that $67 \%$ of the population live under poverty line in 2013. Poverty incidence is higher in the rural areas, $72.4 \%$, and $59 \%$ in urban environment. This trend is shown by other indicators of health: life expectancy falls from 50 years in the 90s to 48 years in 2013; HIV / AIDS prevalence rate increased to $5.9 \%$ in 2010 among people between 15 and 49 years old; maternal and infantile mortality rate grew over time [6]. Malnutrition is the underlying cause of nearly half of all child deaths in CAR. The United Nations Fund for Children (UNICEF) is alarmed by the gross malnutrition of children in the Central African Republic (CAR). The extent of severe malnutrition affecting children in the country, according to figures from the UN agency, reveals nearly 700,000 children under 5 years living below acceptable nutrition thresholds, and many are now on the verge of survival.

The rate of acute malnutrition has reached 16 percent of children under 5 years in the three southern provinces of Mambéré Kadei, Sangha Mbaéré, and Lobaye. 6.6 percent of the same age group are severely acutely malnourished. These rates are far above the emergency thresholds of 2 percent for severe acute malnutrition and 15 per cent for global acute malnutrition, according to UNICEF [7].

The causes of this chronic malnutrition are multiple, according to the UN agency. In the Central African Republic reigns a pervading extreme poverty. Indeed, more than six out of ten people live on less than $\$ 1.25$ per day. The global financial crisis and the displacement of populations due to the ongoing conflict weigh on the economy. This extreme poverty has a negative impact on the realization of human rights as reported by the United Nations. Some rights can only be carried out if minimum acceptable living conditions are reached. In Central African Republic however, the poverty issue and its consequences put children in employment posture.

\subsection{Poverty as Factor Supporting Child Labor}

Children's work was formerly perceived as a socialization process by which they learnt and appropriated their community values. In general, children at birth have no idea of the world to which they belong. They progressively acquire values that contribute to their development. Thus, socialization was meant to have a determining influence on the child all along his/her life. Even if the conception remains more or less justified, it is questioned today.

Indeed, it is observed that children's work is economic-based. Poverty and the child labor are overlapping phenomena. The effects of poverty are especially characterized by extreme misery of populations who live under frightful physical, social and human conditions, malnutrition, difficulty to access and even nonexistence of drinking water, absolute lack of hygiene and schooling infrastructures. To cope with this situation, large families consider that each member has to take part in the survival of the house while satisfying its own needs.

According to the labor law in CAR, a young person can start working at 18 years old for boys and 16 for girls. On the issue, the article 268 of the law No09 / 004 of 29 January 2009 stipulates however that "the work inspector has to give evidence that the work given to the child is recognized below his strengths. The employer has to allot him a suitable work." Unfortunately, minor work in Central African Republic is spreading dangerously in all cities and provinces of the country including Bangui the capital. Very young boys and girls between 10 and 14 years old are present in street corners, in markets and everywhere, carrying on their heads merchandises or working in private houses as servants, fighting to get hypothetic means of survival. 


\subsection{Situation of Education}

Progresses made in the field of education are not sufficient. The number of children attending school does not reach 6,000 children. The gross enrollment rate at the national level remains low: $1.9 \%$ for a total of 9,106 children between 3 to 5 years old.

On the one hand, the number of children enrolled in pre-school has not increased because of the lack or inadequacy of reception infrastructures across the country. On the other hand there is an ignorance of objectives pursued by a maternal school and parents refuse to enroll their children under the age of 6 in pre-school because of the distance from home to school.

Concerning the primary school, teaching conditions remain precarious. The situation is explained by the inadequacy of reception facilities, books or teachers. The practice of classes at mid-time results in the nonobservance of teaching hours schedules and leads to the degradation of the teaching level in primary schools. Furthermore, children with disabilities do not receive proper education, lack of specialized structures necessary to their needs.

\subsection{Sociocultural Obstacles}

To better understand why the Central African society remains reluctant to the outbreak of the rights of the child, it's important to know the perception that this society has of the child.

\subsubsection{Social Perception of the Child}

The child, according to the Central African society, is not an autonomous being, endowed with reason and ability. It is rather considered fragile and incapable, and the society has to protect and guide him/her so that he/she becomes one of its members. Decision is made for him because the society believes it makes the choice that goes in the sole interest of the child. Because of that belief, there are no real criteria to determinate the age of majority. The child becomes an adult, for example, when performing a certain ritual in some traditions. Initiation rites are for boys and circumcision for girls. This perception makes the child a non-autonomous subject who undergoes the dictatorship of the society which does not necessarily take into account its opinion. This negatively influences the rights of the child.

\subsubsection{Influence of Society on the Rights of the Child}

The constitution of the Central African Republic in its articles 6 and 7 gives an important place to the child. Unfortunately, the child is perceived by the society as a small being totally dependent on adults. Everything contributing to its growth, maturity or mental, is taken care of by parents and the village. Families sometimes exchange children, claiming to make sustainable the social bond between families, tribes or lineage. These exchanges are genuine acts of adoption that don't rely on any formal rule. So the system shows deviations because the child becomes an object in the hands of adults who decide his fate at the discretion of their convenience and their relational interests.

Furthermore, the physical integrity of girls is seriously affected by respect to customs and traditions through female circumcision practice and early marriage. Another aspect is the discrimination between girls and boys. Boys are given more importance because they are seen as the ones who perpetuate the lineage. Consequently, inheritance rights don't exist for girls who are regarded as a stranger in their own family. The reason is that one day they will go to live elsewhere with their husbands. Discrimination between girls and boys is accepted and even encouraged.

Discrimination is also visible between children born with a disability and those born "healthy". Indeed, children born with a disability are seen as curse bearers in the family or in society. For that, society gives them little attention. Therefore, it's understandable that the child's right to life relies on the will of the social organization. The superior interest of the child prevailing in the convention of the rights of children loses its value.

In addition, the influence of the society on the right to education is also considerable. In the popular imagination in RCA, pre-school education is assimilated to a simple day care center which offers more fun than educational activities. Therefore some parents refuse to enroll their children of less than 6 years. The net enrolment rate shows that $15 \%$ of children between 6 and 11 years old are not attending school [8].

\section{SUGGESTIONS}

\subsection{Child Labor}

Laws have to severely punish all children's exploitation while defining in a clear and precise way incurred sentences in case of violation. Moreover, legislative and legal dispositions regarding child labor have to provide infrastructures to receive and train exploited children. 


\subsection{Education}

Education is both a fundamental right and a key to exercise the other rights inherent to human person. Education gives children all the means to fully participate in the community life. Education plays a major role, whether it is to make children self-reliant, to protect them from exploitation, works exposing them to danger or sexual abuse, or to promote human rights and democracy.

Giving sense to the right to education requires precise legislation on interdependent values such as allocations, accessibilities, acceptabilities, adaptabilities.

Indeed, allocations imply the existence of sufficient infrastructures and educational programs. Their operation depends on many factors, including the environment for example since buildings or other structures offering shelter have to be provided.

Accessibility also refers to educational institutions and educational programs that should be accessible to all children. It has three dimensions as follow:

- Non-discrimination. Education must be provided to all, especially to vulnerable groups, without discrimination based on any consideration.

- Physical accessibility implies that education should be given in a reasonably accessible place. Children in the countryside, for example, must be able to easily reach their schools.

- Accessibility, from an economic point of view, indicates that education must be economically accessible to all children. Primary education must be compulsory and free to everyone.

Acceptability takes into account the form and content of education, including school curricula and teaching methods which have to be acceptable, relevant and culturally appropriate and of good quality for children and according to the needs of parents.

Adaptability implies teaching flexibility and its adaptation to the needs of societies and communities, as well as the needs of children from different social and cultural levels.

The interest of the learner will only be realized if these interrelated and essential criteria are applied.

\subsection{Justice Institutions for Child}

The justice for minor should first engage in preventing children from abuse. The prevention would consist in having a mediation authority capable of dealing with children issues in a short period of time. It would allow accessing specialized services in the police to address children related questions. These services would be in charge of managing ongoing affairs and facilitating the transmission of documents to the judicial bodies if necessary.

Law has a meaning only if it is justifiable. The justifiability of a law can operate in the aim of claiming, meaning that reparation should be required in case of violation or non-respect when it comes to ensure responsibilities in a situation of law sprain. This is why the constitution of courts adapted to children and their statute appears as fundamental. The institutionalization of courts for child has to be made as separate entity or as sub-division of existing regional courts or districts.

Those courts must have their own procedural rights, with definitions and application of measurements helping to deal with children experiencing a problem with the law. They must function in a strict respect of principles guaranteeing the equity of the lawsuits, and with specialized defenders or other representatives who better master detention or imprisonment situations of children and who are able to offer an adequate assistance.

\subsection{Contribution of the Society}

Here, we intend to define the criteria applicable to parents and civil society organizations in order to help children taking concretely advantage of their rights. The family is considered as the traditional living environment of the child. The respect of questions regarding his/her rights concerns initially the family (parents, tutors, representatives, community, etc). That is why treaties relating to the child rights impose obligations to the parents, tutors or all members of the society in order to support the blossoming and the respect of child rights. Nevertheless the anchoring of obligations implies necessary that above mentioned people know these obligations. The knowledge of obligations also encounters illiteracy problem. In addition to that question, parents and the community must recognize that the child is an autonomous person who is able to think the future.

The respect or application of the rights of child by the parents and the community also depends on financial resources which must be sufficient to fulfill the child's needs. Although civil society organizations assist the government in ensuring its traditional missions (security, providence), it's important that they develop specific childhood protection programs. These programs would concern children in general, but more specifically those who are sick, disables, or those living particular difficulties. Given their increasing number, civil society organizations should coordinate their actions in order to better manage their interventions. The coordination frame should be made at two levels: firstly, between organizations engaged in the protection issue at a local, national and international level, then between organizations and state structures dealing with child protection. 


\section{CONCLUSION}

Through this study, we understood problems impeding children to fully enjoy their rights in Central African Republic. By looking for the causes, we discovered that the political situation of the country contributes considerably to the non compliance of protective measures of the child. The political instability compels governments to pay more attention to political and military questions. In addition to this situation of permanent rebellion, poverty appears as en other element worsening children conditions in Central African Republic.

Our study pointed out the reasons explaining the failure of policy makers and the failure of the law prepared to guarantee effectively children rights. Moreover, the difficulty encountered in applying childhood protection measures is also created by the persistence of socio-cultural barriers. One of major difficulties lies in the definition of the child by the Central African society. This consideration of the child is responsible for the non compliance of children rights by the society. The traditional society considers that these rights are foreign conception that does not correspond to any of their values. Thus, the child is in a double disadvantaged situation, because neither the public authorities nor the society want to give him necessary means for its full blooming. Therefore, a sensitizing, information and education work has to be conducted so that populations perceive the importance of children rights in order to ensure them an adequate protection.

\section{Legal Instruments}

\section{References}

[1] Vienna Convention on the Law of Treaties, Article 27: A party may not invoke the provisions of its internal law as justification for its failure to perform a treaty. This rule is without prejudice to article 46.

[2] Universal Declaration of Human Rights, Article 8: Everyone has the right to an effective remedy by the competent national tribunals for acts violating the fundamental rights granted him by the constitution or by law.

\section{Book}

[3] V. T. Le Vine, Political Leadership in Africa (1967). Hoover Institution Studies Series; 18, The Hoover Institution, Stanford University, 1967, pp. 114.

\section{Online Press Releases}

[4] UNICEF Centrafrique: 1'existence d'enfants soldats publié le 04-01-2013

www.lefigaro.fr/flash-actu

[5] The World report 2013 on the human development of the UNDP classifies the CAR in the 180th rank on 186. Avalable at. hdr.undp.org/en/statistics

[6] Résultats de l'enquête nationale à indicateurs multiples couplée avec la sérologie VIH et anémie en RCA 2006. Published on 200901. Part IV. P35-275. Available on: http://www.childinfo.org/files/MICS3_CAR_FinalReport_2006_Fr.pdf

[7] UNICEF: Malnutrition among children in southern CAR alarming. Press Centre, 11 August 2009. Available at http://www.unicef.org/media/media_50744.html

[8] National Report on the Development of Education in the Central African Republic. 2004-6.part I.p4para 3-4. Available at www.ibe.unesco.org/Internation.P-4al/ICE47/English/Natreps 